\title{
The human glutathionine $S$-transferases
}

\section{Immunohistochemical studies of the developmental expression of Alpha- and Pi-class isoenzymes in liver}

\author{
Christopher HILEY,* Anthony FRYER,* Jeanne BELL, $\dagger$ Robert HUME $\ddagger$ and Richard C. STRANGE* $\S$ \\ *Clinical Biochemistry Research Laboratory, Department of Postgraduate Medicine, University of Keele, Central Pathology \\ Laboratory, North Staffordshire Hospital Centre, Hartshill, Stoke-on-Trent ST4 7PA, U.K., †Department of Pathology, \\ University of Edinburgh, Edinburgh EH9 1UD, Scotland, U.K., and †Department of Child Life and Health, \\ University of Edinburgh, Edinburgh EH9 1UD, Scotland, U.K.
}

\begin{abstract}
Immunohistochemical studies of the developmental expression of the Alpha- and Pi-class glutathione $S$ transferases in human liver have shown that the Pi enzyme is expressed in bile-duct epithelium and some hepatocytes but not in haematopoietic cells. This locus is down-regulated during gestation in hepatocytes but not in epithelium. The enzymes of the Alpha set were also found in only some hepatocytes, and it appears that many cells express neither these nor the Pi forms.
\end{abstract}

\section{INTRODUCTION}

The glutathione $S$-transferases (EC 2.5.1.18) are dimeric enzymes that catalyse the conjugation of GSH with various electrophiles. The human isoenzymes can be conveniently classified as belonging to the Alpha, Mu or Pi sets (Mannervik et al., 1985). The Alpha set comprises various forms that were originally believed to be encoded by the $G S T 2$ locus, but subsequent work suggests they comprise separate monomers, $\mathbf{B}_{1}$ and $\mathbf{B}_{2}$, that are products of different genes (Stockman et al., 1985) situated on chromosome band $6_{\mathrm{p}} 12$ (Board \& Webb, 1987). The monomers can combine to give homodimers $\mathbf{B}_{1} \mathbf{B}_{1}$ and $\mathbf{B}_{2} \mathbf{B}_{2}$ and a heterodimer $\mathbf{B}_{1} \mathbf{B}_{2}$. The Mu-class isoenzymes (Warholm et al., 1983) appear to be the products of a further, polymorphic, locus, GSTI. Pi-class isoenzymes were first described in erythrocytes (Marcus et al., 1978), but subsequently similar forms have been identified in all human tissues. Immunological studies indicate that these are all products of a single locus, GST3 (Pacifici et al., 1985; Guthenberg et al., 1986; Hirrell et al., 1987), that is located on chromosome 11 (Laisney et al., 1983).

The developmental expression of the glutathione $S$ transferases is of interest because these loci demonstrate time- and tissue-specific expression (Strange et al., 1985; Faulder et al., 1987). For example, in liver the GST3 locus is down-regulated during early gestation and at term the enzyme is only weakly expressed (Strange et al., 1985). Further, whereas the expression of $B_{1}$ appears to be constant during development, $\mathbf{B}_{2}$ is weakly expressed, compared with adult samples, even 1 year after term delivery (Faulder et al., 1987).

The interpretation of biochemical data obtained from studies of developing tissues can, however, pose problems (Jones, 1982). The cellular composition of foetal liver alters substantially during development (Valdes-Dapena, 1979). Between 12 and 24 weeks gestation it is a site of haematopoiesis, with erythroid and myeloid cells constituting more than $50 \%$ of the hepatic cell population of the 22-week embryo, whereas by term haematopoietic cells constitute less than $2 \%$ of total hepatic cell volume. It is possible, therefore, that apparent developmental changes in enzyme expression, as determined by biochemical assay, are the result of altered cellular composition rather than the switch on or off of particular genes.

Furthermore, studies that utilize homogenized liver do not permit localization within the lobule of particular metabolic activities. In adults an enzyme may not be uniformly distributed throughout the parenchyma, since some activities are largely carried out in periportal cells, while others are performed predominantly in centrilobular cells (Jungermann \& Katz, 1982). Such metabolic heterogeneity may not exist in developing liver, since the large periportal to periarterial gradients for hormones and $p \mathrm{O}_{2}$, characteristic of adults, are unlikely to be present. It is possible, however, that there are metabolic differences between the right and left hepatic lobes (Jones, 1982).

There are no data on the distribution of the glutathione $S$-transferases in human foetal liver, and we now describe immunohistochemical studies that determine the cellular location of the Alpha and Pi sets during development.

\section{MATERIALS AND METHODS}

\section{Tissue samples}

Samples of tissues were obtained, except where stated, from the right hepatic lobe within $4 \mathrm{~h}$ of death from 35 aborted foetuses (12-24 weeks gestation) following termination of pregnancy, four premature and term infants (28-42 weeks gestation) who died in the neonatal period and four infants who suffered sudden infant death syndrome (11-41 weeks of postnatal age after term delivery). The aims and methods of the study were approved by the Reproductive Medicine Ethics Committee of the Simpson Memorial Maternity Pavilion, Royal Infirmary, Edinburgh. Samples were also obtained from 15 adults within $6 \mathrm{~h}$ of death at autopsy with the permission of Her Majesty's Coroner. 


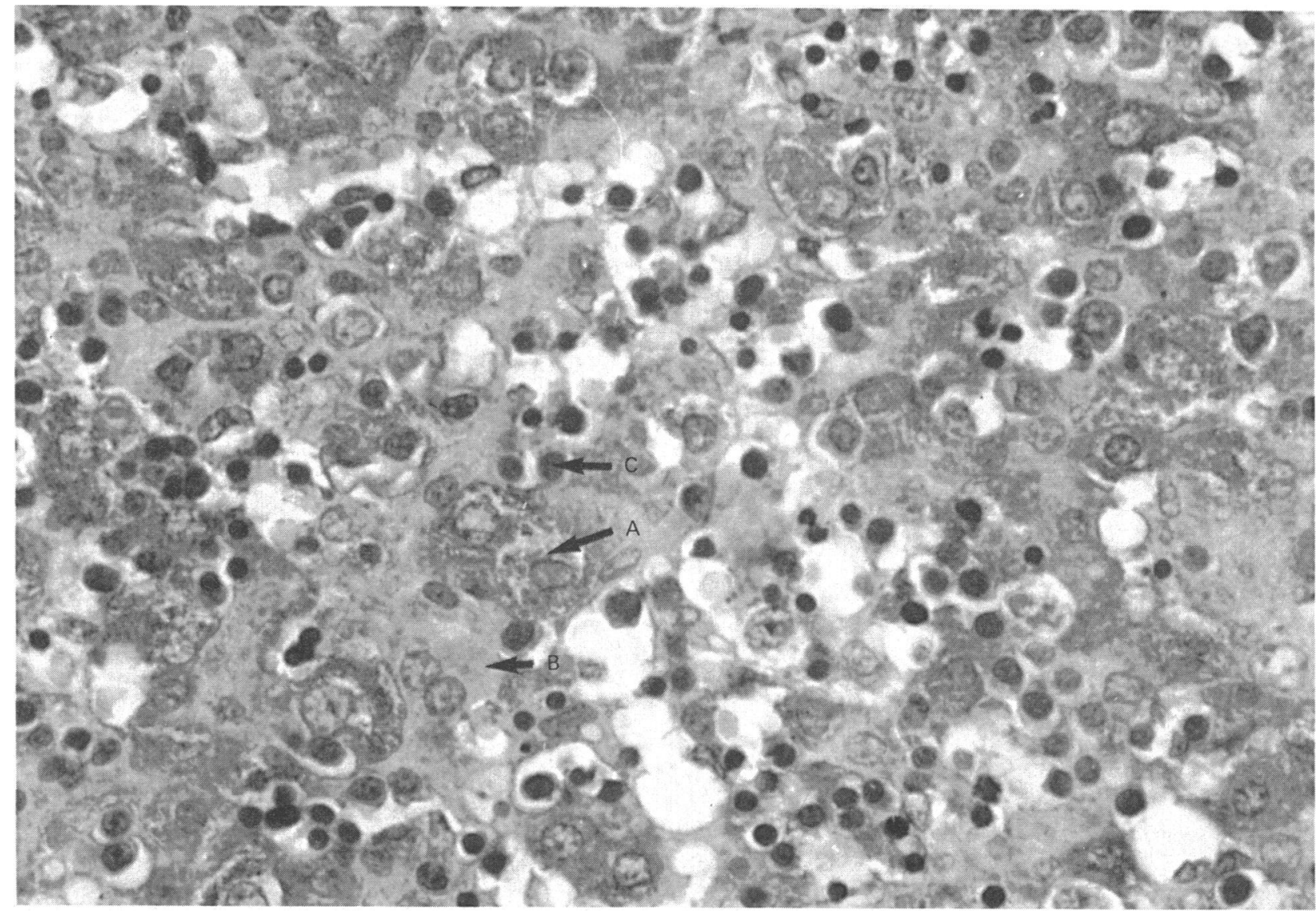

Fig. 1. Expression of the Pi-class glutathione $S$-transferase isoenzyme in foetal liver

Sections were taken from a liver obtained after 13 weeks of gestation, and the Pi enzyme was detected by immunohistochemistry with the use of polyclonal antiserum. The Figure shows A, hepatocyte demonstrating positivity for the Pi isoenzyme, B, hepatocyte negative for the Pi form, and $\mathrm{C}$, haematopoietic cell. Magnification $\times 500$.

\section{Purification of Alpha-class glutathione $S$-transferase $\left(\mathbf{B}_{1} \mathbf{B}_{1}\right)$}

Ice-cold $20 \mathrm{~mm}$-Tris/HCl buffer, pH $7.30(30 \mathrm{ml})$, containing $250 \mathrm{~mm}$-sucrose, $0.1 \mathrm{mM}$-EDTA and $1 \mathrm{~mm}$ GSH was added to pieces of adult liver (5-10 g). The tissue was cut into small pieces, homogenized, centrifuged $\left(20000 \mathrm{~g}\right.$ for $30 \mathrm{~min}$ at $\left.4^{\circ} \mathrm{C}\right)$, re-centrifuged $(150000 \mathrm{~g}$ for $60 \mathrm{~min}$ at $4{ }^{\circ} \mathrm{C}$ ) and the resulting supernatant termed cytosol.

Cytosol (12 ml; approx. $20 \mathrm{mg}$ of protein $/ \mathrm{ml})$ was eluted $\left(3.5 \mathrm{ml} / \mathrm{min}\right.$, at $\left.4^{\circ} \mathrm{C}\right)$ from a DEAE Zetaprep 15 disc (LKB Instruments) with $20 \mathrm{~mm}$-Tris $/ \mathrm{HCl}$ buffer, pH 7.30, and activity in the 'flow-through' fractions was pooled and dialysed $\left(16 \mathrm{~h}\right.$ at $\left.4{ }^{\circ} \mathrm{C}\right)$ against 2 litres of $10 \mathrm{~mm}$-sodium phosphate buffer, $\mathrm{pH} 6.70$, containing $1 \mathrm{mM}-\mathrm{GSH}$ and $0.1 \mathrm{~mm}$-EDTA.

The dialysis residue was applied to a column $(40 \mathrm{~cm}$ $\times 1.6 \mathrm{~cm}$ ) containing CM-cellulose equilibrated with $10 \mathrm{~mm}$-sodium phosphate buffer, $\mathrm{pH} 6.70$, at $4^{\circ} \mathrm{C}$. After $80 \mathrm{ml}$ had been eluted an $\mathrm{NaCl}$ gradient was established by adding buffer containing $120 \mathrm{mM}-\mathrm{NaCl}$ to a reservoir containing $450 \mathrm{ml}$ of the phosphate buffer. This reservoir was used to supply the column $(30 \mathrm{ml} / \mathrm{h})$. Fractions $(2.5 \mathrm{ml})$ were assayed for activity and $\mathrm{Na}^{+}$concentration.

The peak of activity that was eluted at $41 \mathrm{~mm}-\mathrm{Na}^{+}$ corresponded to $\mathbf{B}_{1} \mathbf{B}_{1}$. These fractions were pooled, dialysed $\left(6 \mathrm{~h}\right.$ at $\left.4^{\circ} \mathrm{C}\right)$ against $2 \times 2$ litres of $25 \mathrm{mM}$ ethanolamine buffer, $\mathrm{pH} 9.40$, and eluted $(30 \mathrm{ml} / \mathrm{h}$, at $\left.4^{\circ} \mathrm{C}\right)$ from a column $(40 \mathrm{~cm} \times 1.0 \mathrm{~cm})$ containing Polybuffer exchanger 94 previously equilibrated with start buffer ( 25 mm-ethanolamine buffer, $\mathrm{pH} 9.40)$. The pH gradient was formed with 1:10-diluted Polybuffer 96 adjusted to $\mathrm{pH} 7.00$ with $1 \mathrm{M}-\mathrm{HCl}$. Fractions $(2.5 \mathrm{ml})$ were assayed for activity and $\mathrm{pH}$. The first peak of activity, eluted at $\mathrm{pH} 8.80$, was pooled and eluted $(15 \mathrm{ml}$, at $\left.4{ }^{\circ} \mathrm{C}\right)$ from a column $(8 \mathrm{~cm} \times 0.8 \mathrm{~cm})$ containing $S$ hexylglutathione linked to epoxy-activated Sepharose 6B equilibrated with 10 mM-sodium phosphate buffer, pH 7.00. After $40 \mathrm{ml}$, the column was eluted with $50 \mathrm{~mm}$-Tris/ $\mathrm{HCl}$ buffer, pH 9.00 , containing $5 \mathrm{~mm}-$ GSH. Pooled peak fractions were dialysed $(18 \mathrm{~h}$ at $4{ }^{\circ} \mathrm{C}$ ) against 5 litres of $50 \mathrm{~mm}$-ammonium acetate buffer, pH 8.5, and concentrated (6-fold) in an Amicon Centricon 10 microconcentrator. Homogeneity was confirmed by the presence of a protein band of $M_{\mathrm{r}} 24300$ on SDS/polyacrylamide-gel electrophoresis (Hirrell et al., 1987).

Antiserum to the Alpha-class $\left(B_{1} B_{1}\right)$ isoenzyme was prepared in sheep by subcutaneous injection of the purified antigen as previously described for the Piclass form (Hirrell et al., 1987). The avidity of the antiserum was confirmed by inhibition of enzyme activity, double immunodiffusion, immunoelectrophoresis and 


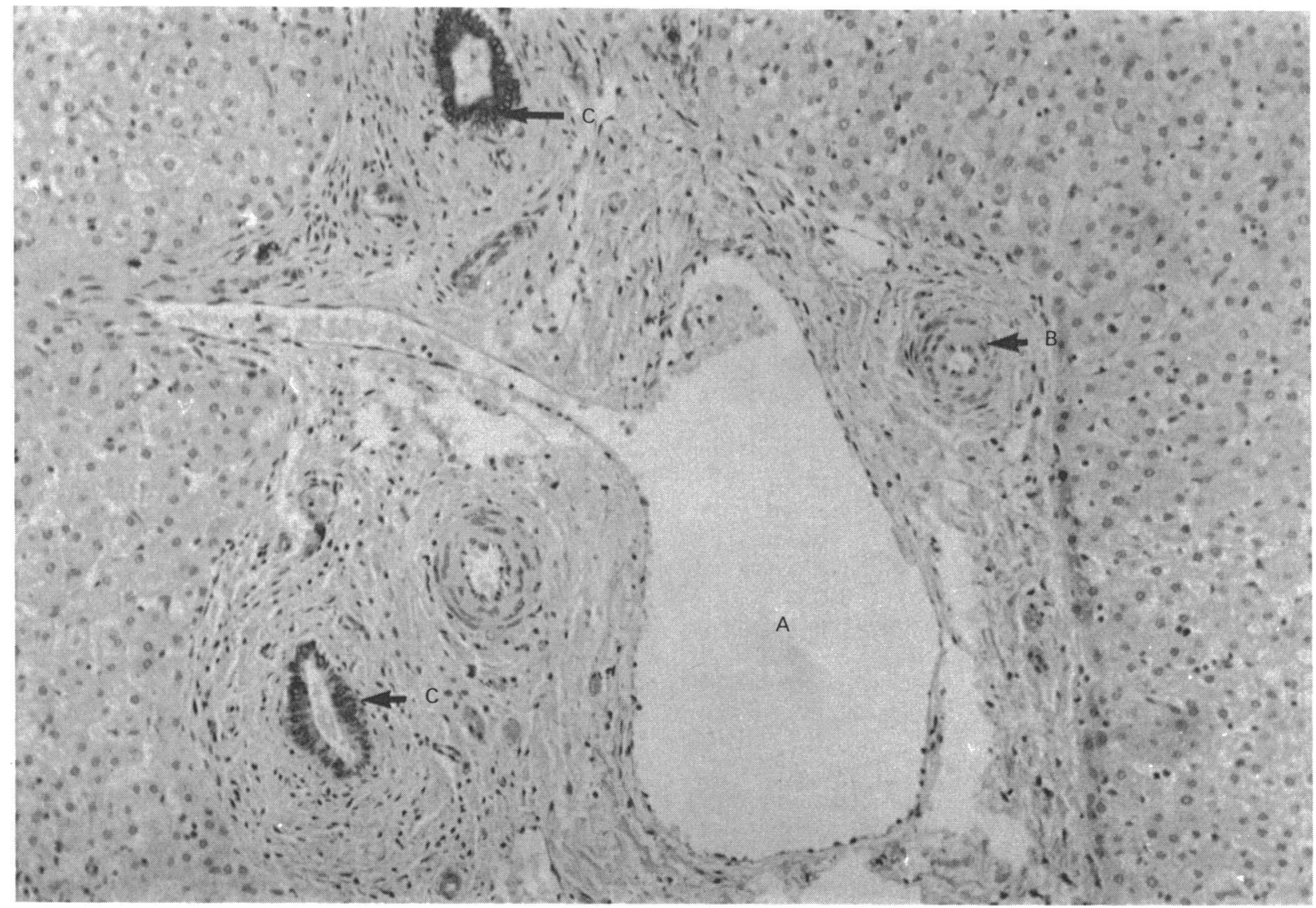

Fig. 2. Expression of the Pi-class glutathione $S$-transferase isoenzyme in neonatal liver

Sections were taken from a liver obtained after 8 weeks postnatal age and the Pi isoenzyme was detected as indicated in Fig. 1 legend. A portal tract is shown comprising A, portal vein, B, portal artery, and C, bile ducts. The bile-duct epithelium shows intense positivity for the $\mathrm{Pi}$ isoenzyme. Magnification $\times 125$.

immunoblotting (Western blots) (Hirrell et al., 1987). Studies using immunoelectrophoresis showed, firstly, that there was no detectable cross-reaction between antiserum to the Pi isoenzyme and the Alpha, Mu (GST1 $1, G S T 12$ ) or GST4 isoenzymes, and, secondly, that antiserum to $B_{1} B_{1}$ cross-reacted equally with the Alpha basic forms but not isoenzymes encoded by the other loci.

\section{Immunohistochemistry}

Liver samples were fixed in buffered $10 \%$ formalin and processed routinely to paraffin wax, and sequential $5 \mu \mathrm{m}$ sections were cut. The first section was stained with haematoxylin and eosin, the second with anti- $\mathbf{B}_{1} \mathbf{B}_{1}$ serum and the third with anti-(Pi isoenzyme) serum by using the avidin-biotin-complex method (Hsu et al., 1981). All sections were deparaffinized and rehydrated. Endogenous peroxidase activity was blocked by immersing slides in $30 \%(\mathrm{w} / \mathrm{v}) \mathrm{H}_{2} \mathrm{O}_{2} /$ methanol $(1: 2, \mathrm{v} /$ v). Slides were washed in water and phosphate-buffered saline $(150 \mathrm{~mm}-\mathrm{NaCl} / 5 \mathrm{~mm}$-sodium phosphate buffer, pH 7.2) and incubated with donkey serum diluted $1: 3$ in phosphate-buffered saline for $30 \mathrm{~min}$ at $22^{\circ} \mathrm{C}$ in a humidity chamber. The serum was replaced with the primary sheep anti-(human $\left.\mathbf{B}_{1} \mathbf{B}_{1}\right)$ or anti-(Pi isoenzyme) serum diluted 1:100 in phosphate-buffered saline.

After incubation $\left(30 \mathrm{~min}\right.$ at $\left.37^{\circ} \mathrm{C}\right)$, sections were washed $(3 \times)$ in phosphate-buffered saline and incubated $\left(30 \mathrm{~min}\right.$ at $\left.37^{\circ} \mathrm{C}\right)$ with biotinylated donkey anti-(sheep IgG) antibody (diluted 1:200 in phosphate-buffered saline). After washing $(3 \times)$, samples were incubated with the avidin-biotin-peroxidase complex $(30 \mathrm{~min}$ at $\left.37^{\circ} \mathrm{C}\right)$, then washed $(3 \times)$ to remove excess antibody and the antigenic sites were detected with diaminobenzidine $(0.5 \mathrm{mg} / \mathrm{ml}$ in phosphate-buffered saline $)$. The reaction was initiated by addition of 1 drop of $10 \%(w / v) \mathrm{H}_{2} \mathrm{O}_{2}$. Samples were left for $10 \mathrm{~min}$, washed in running tap water, dehydrated in ascending grades of ethanol, cleared in xylene and mounted in synthetic resin. In control sections of all samples, the primary antibody was omitted and sections were incubated with normal donkey serum diluted with phosphate-buffered saline.

\section{RESULTS}

\section{Qualitative histology}

Sections of foetal liver stained with haematoxylin and eosin were examined by light-microscopy. Between 12 and 24 weeks gestation liver tissue comprised hepatocytes arranged in double cords together with large numbers of haematopoietic cells in and around the sinusoids. Developing portal tracts were also visible containing bile ducts and portal blood vessels usually surrounded by a conspicuous collar of mesenchyme. 
After 24 weeks gestation the numbers of haematopoietic cells progressively declined so that by 40 weeks gestation only small islands of these cells were seen. The portal tracts appeared similar to those in sections obtained from adult livers.

Hepatocyte cell and nuclear sizes were regular during development, indicating that all cells were diploid.

\section{Expression of Pi-class enzyme (GST3)}

Up to 24 weeks gestation hepatocytes were mostly positive for the $\mathrm{Pi}$ isoenzyme, although examples of cells that did not stain were also seen. In some samples positive were intermixed with negatively staining cells, and in others there were areas of cells demonstrating positivity separated from areas in which the hepatocytes did not appear to express the locus (Fig. 1). Examination of serial sections showed that positively staining cells had an open granular cytoplasm when stained with haematoxylin and eosin, whereas negatively staining cells demonstrated an amorphous cytoplasm. The epithelium of developing bile ducts in the primitive portal tracts also demonstrated strong positivity. Haematopoietic cells, however, were consistently negative.

After 24 weeks gestation hepatocytes became progressively less positive, although bile-duct epithelium remained strongly positive (Fig. 2).

In samples of adult liver the epithelium of large bile ducts within the portal tracts as well as the minor bile ducts within the parenchyma were strongly positive for the $\mathrm{Pi}$ isoenzyme. There was also dense staining of the mononuclear series. Hepatocytes were negative or occasionally very weakly positive for this isoenzyme. Kupffer cells and bile canaliculi were negative.

\section{Expression of Alpha-class isoenzymes (GST2)}

The distributions of the Alpha-class isoenzymes in foetal and adult livers were similar. There was no evidence of enzyme expression in the epithelium of the small bile ducts, but the epithelium of the large ducts contained occasional positive cells in both foetal and adult livers. As in the case of the Pi isoenzyme, only some hepatocytes expressed Alpha-class isoenzymes. Unlike the $\mathrm{Pi}$ isoenzyme, however, expression of the Alpha class was found in hepatocytes from adult livers. Haematopoietic cells, Kupffer cells and bile canaliculi were negative.

\section{Comparison of Pi- and Alpha-class expression}

Examination of serial sections showed that those hepatocytes that expressed the $\mathrm{Pi}$ isoenzyme also expressed Alpha-class isoenzymes. Some hepatocytes therefore did not express either of the enzyme sets. In the foetal and adult samples examined the intensities of staining of both the Pi- and Alpha-class isoenzymes in periportal and centrilobular hepatocytes were similar. Comparison of sections obtained from the left and right lobes from one liver also showed similar expression of both enzyme classes.

\section{DISCUSSION}

Liver demonstrates apparent down-regulation of the GST3 locus during development (Strange et al., 1985; Faulder et al., 1987), but because the cellular composition of the tissue changes during gestation it is not clear from these biochemical studies that gene expression is altered.
The Pi-class isoenzyme is expressed consistently in erythrocytes during development (Strange et al., 1980), and it might be expected that haematopoietic cells would express GST3, and that as blood-cell production declines the hepatic content of this enzyme would decrease. Our data, however, show that GST3 is expressed in foetal hepatocytes and bile-duct epithelium but not in haematopoietic cells, indicating that gene expression is altered during development. The activity in erythrocytes is low compared with liver (Strange et al., 1980), and our failure to detect the enzyme in haematopoietic cells is presumably because the isoenzyme is below the detection limits of the staining method. Although expression in hepatocytes declined during development, that in bileduct epithelia remained constant, and we believe it is enzyme from these cells that is detected in homogenates of adult liver (Strange et al., 1985).

The distribution of the Alpha-class isoenzymes was rather different, since they were usually expressed only in hepatocytes. The antiserum used was raised against $B_{1} B_{1}$, but the $B_{1}$ and $B_{2}$ monomers are so similar that under the conditions used it would be expected to crossreact with both hetero- and homo-dimers (Stockman et al., 1985).

Alpha- and Pi-class isoenzymes were expressed in only some hepatocytes. Since the Mu-class isoenzymes, the products of $G S T 1$, the other locus expressed in liver, are not detectable until about 30 weeks gestation (Strange et al., 1985) and almost half the adults examined in population surveys demonstrate a null phenotype (GSTI 0) for this locus (Strange et al., 1985), it appears that many foetal and adult hepatocytes contain no glutathione $S$-transferase activity. In this regard expression of these enzymes is similar to that of other hepatic proteins. Thus Feldmann \& Maurice (1977) showed that only onethird of human and rat hepatocytes contained albumin, and that $10 \%$ or less contained $\alpha_{1}$-antitrypsin or caeruloplasmin. Cells containing these proteins appeared to be randomly distributed within a lobule, and like the glutathione $S$-transferases without preferential centrilobular or periportal distribution. Unlike the glutathione $S$-transferases, however, the distribution of these proteins did vary among liver lobules, with some lobules not containing any positive cells. Le Rumeur et al. (1981) have suggested that variability in hepatocyte protein production in adult rat liver is dependent on ploidy. We found hepatocyte cell and nuclear size, however, to be regular during development, suggesting that all cells were diploid.

Lamers et al. (1987) have suggested that emergence of periportal and centriacinar patterns of protein expression is linked to maturation of acinar architecture. We found no evidence that the apparently random distribution of Alpha- and Pi-class enzyme expression seen early in development is replaced by a zonal pattern in more mature liver. Rather, the early widespread distribution of the Pi enzyme was gradually curtailed until only bileduct epithelium expressed the locus. It is not surprising that hepatocytes and epithelium express the GST3 locus in early development, since both are of endodermal foregut origin (Valdes-Depena, 1979). It is not clear, however, why epithelium continues to express this gene while it is down-regulated in hepatocytes.

We thank Mr. F. Brian for his advice and support, Dr. A. Bradwell and Mr. R. Drew for production of antisera, and the 
West Midlands Regional Health Authority, the Royal College of Obstetricians and Gynaecologists (Birthright) and the Chest Heart and Stroke Association for financial support.

\section{REFERENCES}

Board, P. G. \& Webb, G. C. (1987) Proc. Natl. Acad. Sci. U.S.A. 84, 2377-2381

Faulder, C. G., Hirrell, P. A., Hume, R. \& Strange, R. C. (1987) Biochem. J. 241, 221-228

Feldmann, G. \& Maurice, M. (1977) in Membrane Alterations as Basis of Liver Injury (Popper, H., Bianchi, L. \& Reutter, W., eds.), pp. 61-76, MTP Press, Lancaster

Guthenberg, C., Warholm, M., Rane, A. \& Mannervik, B. (1986) Biochem. J. 235, 741-745

Hirrell, P. A., Hume, R., Fryer, A. A., Collins, M., Drew, R., Bradwell, A. R. \& Strange, R. C. (1987) Biochim. Biophys. Acta 915, 371-377

Hsu, S. M., Raine, L. \& Fanger, H. (1981) Am. J. Clin. Pathol. 75, 816-821

Jones, C. T. (1982) in Biochemical Developments of the Fetus and Neonate (Jones, C. T., ed.), pp. 249-286, Elsevier Biomedical Press, Amsterdam

Jungermann, K. \& Katz, N. (1982) in Metabolic Compartmentation (Sies, H., ed.), pp. 411-435, Academic Press, New York

Received 15 April 1988/3 June 1988; accepted 16 June 1988
Laisney, V., Cong, N. V., Gross, M. S., Parisi, I., Foubert, C., Weil, D. \& Frezal, J. (1983) Ann. Genet. 26, 69-74

Lamers, W. H., Janzen, J. W. G., te Kortschot, A., Charles, R. \& Moorman, A. F. M. (1987) Differentiation 35, 228235

Le Rumeur, E., Beaumont, C., Guillouzo, C., Rissel, M., Bourd, M. \& Guillouzo, A. (1981) Biochem. Biophys. Res. Commun. 101, 1038-1044

Mannervik, B., ^̊lin, P., Guthenberg, C., Jensson, H., Tahir, M. K., Warholm, M. \& Jörnvall, H. (1985) Proc. Natl. Acad. Sci. U.S.A. 82, 7202-7206

Marcus, C. J., Habig, W. H. \& Jakoby, W. B. (1978) Arch. Biochem. Biophys. 188, 287-293

Pacifici, G. M., Warholm, M., Guthenberg, C., Mannervik, B. \& Rane, A. (1985) Biochem. Pharmacol. 35, 1616-1619

Stockman, P. K., Beckett, G. J. \& Hayes, J. D. (1985) Biochem. J. 227, 1-7

Strange, R. C., Johnston, J. D., Coghill, D. R. \& Hume, R. (1980) Biochem. J. 188, 475-479

Strange, R. C., Davis, B. A., Faulder, C. G., Cotton, W., Bain, A. D., Hopkinson, D. A. \& Hume, R. (1985) Biochem. Genet. 23, 1011-1028

Valdes-Dapena, M. A. (1979) Histology of the Fetus and Newborn, pp. 245-264, W. B. Saunders Co., Philadelphia

Warholm, M., Guthenberg, C. \& Mannervik, B. (1983) Biochemistry 22, 3610-3617 